\title{
The Mediating Role of Perceived Value on The Relationship Between Service Quality, Destination Image, and Revisit Intention: Evidence From Umbul Ponggok, Klaten Indonesia
}

\author{
Rangga Restu Prayogo1, Darwati², Ananda Mellyssa Quratul ain ${ }^{3}$ \\ Department Master of Business Administration \\ Diponegoro University, Semarang, Indonesia \\ ranggarestuprayogo@yahoo.com ${ }^{1}$,darwati@gmail2, anandamellysa@yahoo.com ${ }^{3}$
}

\begin{abstract}
Tourists' perceptions of service quality, destination image, perceived value, and revisit intention are vital successful destination marketing. This study aims to investigate the impact the interactivity of service quality, destination image, and perceived value toward revisit intention to umbul ponggok, Klaten. The conceptual model was developed on the basis of existing theoretical and empirical research in the fields of marketing and tourism. Questionnaire given tourists visit to umbul ponggok and using sampling through the non probability approach using convenience sampling. A total of 183 questionnaires were returned and the data were analysed using structural equation model (SEM). The findings illustrate that service quality positive and significant impact on perceived value and revisit intention. Destination image was found to have a positive and significant impact on perceived value and revisit intention. Implications and future research issues were discussed.
\end{abstract}

Keywords: Service Quality, Destination Image, Perceived Value, Revisit Intention, Indonesia Tourism

\section{INTRODUCTION}

The development of tourism sector in almost countries in Asia Pacific is growing rapidly and may be avowed as one of the most important economic resources in a country (Horng, Liu, Chou, \& Tsai, 2012). Onward prospects of tourism will be very promising as stated by world tourism organizations (UNWTO) that the tourism sector by 2020 in Asia Pacific is estimated to reach 438 million tourists and USD 2 trillion revenues (Gurtner, 2016; Law, Lacy, Lipman, \& Jiang, 2016). Tourism has been one of the largest and fastest factor to grow a good economical country especially one that develops mainly in Mediterranean. But economic changes, political and social in various countries in Asia have been continuously changing and creating tourism environment as well as increasing competition between countries developing tourism sector to attract tourists in visiting its country by developing both product and service (Vitouladiti, 2014). Then, world considers the tourism potential has become a tool to improve and develop country's economy
(Croes, 2006). One of the countries that develop the tourism service is Indonesia.

Indonesia is the largest archipelago in the world with 17,508 islands with five major islands, namely Sumatra, Java, Kalimantan (Borneo), Sulawesi and Papua. Indonesia is located along 3,977-mile between the Indian Ocean and the Pacific Ocean. It is not surprising that Indonesia continuously gives an amazing surprise. Along with economic growth, Indonesian tourism promotion should be supported by increasing of cost per capita. Developing a complete information technology and transportation are also very supportively needed for the growth of tourism accessibility in particular area. Tourism growth should also be accompanied by increasing quality and variety of promotions which conducted including by community involvement and community empowerment (charge of empowerment) in certain areas (Henderson, 2016). One of the most potential tourism areas in Indonesia which needs more surveillance is Klaten, Central Java.

Central Java has outstanding natural beauty such as Borobudur, well-known mountains such as 
Deng, Merbabu, Sumbing, Prau, and many more. Umbul ponggok is currently the most-looked for by tourists in Klaten. Umbul ponggok is an alternative favorite destination for tourists because of the uniqueness of a common large pool in which tourists can feel the freshness streaming down from the mountain and various fishes by snorkeling - which attract tourists to repurchase. The development of tourism strategy is a benchmark for tourists reference is used to select destination. The development of tourism strategy should focus on brand development, marketing strategy, and other factors (Konecnik \& Gartner, 2007). Well-developed tourism strategy will emerge the intention to repurchase Umbul ponggok.

Intentions have been redefined as a willingness to visit specific destinations (Chen, Shang, \& Li, 2014). Intention to repurchase refers to tourists' feeling in particular interval to build subjective perception which affects behavior and final decision (Whang, Yong, \& Ko, 2016). Intention to repurchase is formed through rationality and decisions (Kim \& Jun, 2016). Revisit intention refers to the possibility of onsite feeling for certain period (Whang et al., 2016). One factor to revisit is Destination image (Abubakar \& Ilkan, 2016). Destination image is an impression or expression obtained by a tourist on his journey. Destination image is antecedents in revisiting certain area in future (Ramseook-Munhurrun, Seebaluck, \& Naidoo, 2015).

Furthermore, the intention to repurchase can be affected by the quality of service that travelers obtain while traveling, the overall quality to impression of customers who receive service in accordance with expectations (Zhang, Wang, Min, Chen, \& Huang, 2016). By then, quality of service canevoke travelers' intention to revisit and obtain impression (Tosun, Dedeolu, \& Fyall, 2015). Then, intentions to revisit can be influenced by destination image and quality of service through the perceived value. With the destination image and perceived service quality will create perceived value to produce the revisit intention (Rasoolimanesh, Dahalan, \& Jaafar, 2016). In accordance to explanation, this study was conducted to look at aspects influence a travelers' to revisit this is destination image, service quality, and perceived value in Umbul ponggok. This study will provide a source of information and theories about the relations and influences of destination image, service quality, and perceived value in revisiting Umbul ponggok.

\section{THEORETICAL BACKGROUND AND HYPOTHESES}

\section{A. Destination Image, Perceived Value, and Revisit Intention}

Destination image is an impression or expression obtained by a tourist on his journey (Ramseook-Munhurrun et al., 2015). Destination image is a combination of a variety of products, attractions, attributes and personal perception through information selection. Destination image play an important role in decision-making (Whang et al., 2016). Perceived value is consumers' overall assessment about the utility of products / services based on received and perceived (Rasoolimanesh et al., 2016). Perceived value is also related to what being perceived toward received value when making appropriate travel planning to travel services (Ramseook-Munhurrun et al., 2015). Thus, the destination image can affect the perceived value obtained when traveling (RamseookMunhurrun et al., 2015). Many studies state that destination image positively and significantly affect perceived value ( $\tilde{A} \&$ Tsai, 2007; Rasoolimanesh et al., 2016). However, the results also show destination image does not significantly influence the perceived value in China (Horng et al., 2012). Destination image affects the intention of tourists to revisit. Based on the results destination image positively and significantly affect the revisit intention (Tosun, Dedeolu, \& Fyall, 2015; Whang et al., 2016). However, the result also shows that the destination image does not significantly influence the revisit intention in Greece (Stylos, Vassiliadis, Bellou, \& Andronikidis, 2016). So the approach based on existing literature and theory, it can be hypothesized that:

H1: destination image positively and significantly affects the perceived value

H2: destination image positively and significantly affects revisit intention

H3: destination image positively and significantly affects revisit intention through perceived value 


\section{Service Quality, Perceived Value, and Revisit Intention}

Service quality is the result of process of evaluation in which consumers compare expectations and reality or with received services (I. K. W. Lai \& Hitchcock, 2016). Quality of service can also distinguish between the expectations of customers who received and perceived service from a particular place (Kuo, Wu, \& Deng, 2009). Perceived value associates with received, perceived and remembered process and valued by consumer / tourist. Perceived value is specifically derived from consumers' feelings about received and incurred fees as the quality obtained (W. Lai \& Chen, 2011). Furthermore, perceived value is also about consumer's value perception of trade-off between qualities or the benefits the product associated with the consumer's sacrifices (Manoj, 2011). Many researches have shown that service quality may affect consumer's perceived value (Dye, Groth, \& Dye, 2007; Hapsari, Clemes, \& Dean, 2016; Kuo et al., 2009). Therefore, good service possibly make the tourists have revisit intention in the same place because revisit intention refers to the possibility of certain feeling to build subjective perception that affects final decision (Whang et al., 2016). Several studies have been done to see the positive relations and influence between service quality and revisit intention. From the study (Liu \& Lee, 2016) says service quality influences tourists' decision to revisit using transportation in Taiwan. Another research in Alanya, Turkey tourism spot, by providing good services may influence tourists to revisit the same place (Tosun et al., 2015). Revisit intention is also influenced by service quality which is provided by a shopping mall in Taiwan (Kuo et al., 2009). In sum, the role of the quality services provided may affect the revisit intention the same place. So based on given literature and theory approach, it can be hypothesized :

H4: Service quality positively and significantly affects perceived value

H5: Service quality positively and significantly affects revisit intention

H6: Service quality positively and significantly affects revisit intention through perceived value

\section{Perceived Value and Satisfaction}

Perceived value is consumer's general perception of product/service purposes based on received and perceived perception (Rasoolimanesh et al., 2016). Perceived value is also related to whole perception on received value during trip based on tour service's plan (RamseookMunhurrun et al., 2015). Perceived value is also opinion about money, quality, benefits, and social psychology in conducting an assessment of a product or service (Kuo et al., 2009). Perceived value is also associated with consumer / process rating performed on the received, perceived and remembered. More specifically, Perceived value is derived from consumers' feelings about the fees received and costs incurred as the quality obtained (W. Lai \& Chen, 2011). Furthermore, perceived value is also about consumer's value perception of trade-off between quality and the benefits of product associated with the sacrifices to pay (Manoj, 2011). Revisit intention is the result of the perception based on previous experiences (Horng et al., 2012). According to (Ferns \& Walls, 2012), it emphasizes the revisit intention in context of tourism within a certain period so as to create an intention to visit. Then, the revisit intention evokes based on quality and value within a journey to revisit (Liu \& Lee, 2016). Findings show that perceived value positively and significantly affects revisit intention (Rasoolimanesh et al., 2016; Sultan, 2012). However, other studies also show that perceived value cannot affect the intention significantly (Kuo et al., 2009). So based on given literature approach, it can be hypothesized that:

H7: perceived value positively and significantly affects revisit intention 


\section{Hypothesis Model}

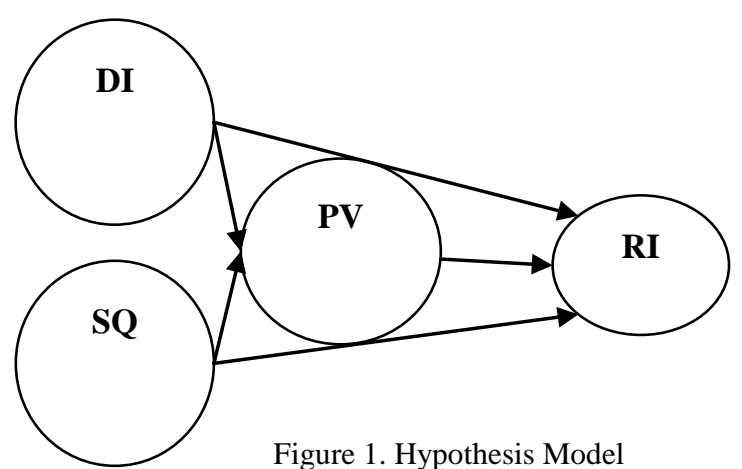

Figure 1. Hypothesis Model

\section{RESEARCH METHODS}

Empirical studies conducted in Umbul ponggok and domestic tourists chosen as target population. The precise data of size and population's location was unidentified so that probability could not be applied as well. Sample collection techniques used in this case was nonprobability sampling in which convenience sampling on tourists / visitors Umbol ponggok. The measurement used in this study is scale of 1 to 5 (Likert). For size, though 200 questionnaires were initially distributed, 17 questionnaires were rejected because filled improperly. Thus, 183 respondents were available as object of research. Distributing questionnaires done in August of 2016. Then after distributing questionnaires, data was processed by the researcher. The model used in this research is Structural Equation Modeling (SEM) with WarpPLS 3.0 statistical techniques as a tool to test the data. Result obtained $44.2 \%$ were male respondents and $55.2 \%$ were female. $38.8 \%$ respondents were high school graduated and the least was from graduated school which filled 9.2\%. By $55.2 \%$ tourists are still dominated by tourists coming from Java and the remaining $44.8 \%$ coming from Sumatra, Bali and Sulawesi. 50.2\% of age who visited Umbul ponggok ranged from 20-30 years old and the least $12.1 \%$ and aged from $45-60$ years old.

Table 1. Tourist Characteristics in Umbul Ponggok

\begin{tabular}{|l|c|c|}
\hline & Frequency & $\begin{array}{c}\text { Percentage } \\
(\%)\end{array}$ \\
\hline Origin & & \\
\hline Java Island & 101 & $55.2 \%$ \\
\hline
\end{tabular}

Table 1 , cont.

\begin{tabular}{|l|c|c|}
\hline Non-Java & 82 & $44.8 \%$ \\
\hline Gender & & \\
\hline Male & 81 & $44.2 \%$ \\
\hline Female & 102 & $55.8 \%$ \\
\hline Age(years) & & \\
\hline $20-30$ & 92 & $50.2 \%$ \\
\hline $30-45$ & 69 & $37.7 \%$ \\
\hline $45-60$ & 22 & $12.1 \%$ \\
\hline Education & & $38.8 \%$ \\
\hline Senior & 71 & $18.6 \%$ \\
\hline College & 34 & $33.4 \%$ \\
\hline University & 61 & $9.2 \%$ \\
\hline $\begin{array}{l}\text { Graduate } \\
\text { school }\end{array}$ & 17 & \\
\hline
\end{tabular}

\section{a. Questionnaire Instrument}

Statement / items test adapted from an instrument used in previous research, testing variable of destination image adapted from research (Stylos et al., 2016; Tan, 2016; Tosun et al., 2015; Whang et al., 2016), that the dimensions of destination image is divided into effective and cognitive image. Furthermore, to test the quality of service variables adapted from research (Kuo et al., 2009; Liu \& Lee, 2016; Zhang et al., 2016), that dimension is divided into visible and reliable. Then, to test the perceived value variable adapted of the study (Dye et al., 2007; Kuo et al., 2009), that the dimension is divided into product and Service value. Finally, to test the intentions to revisit variable adapted from the study (Liu \& Lee, 2016; Tan, 2016; Tosun et al., 2015), that the dimension is divided into the revisit intention and intensity of visiting time. 
Table 2.

Result of Loading, Average Variance Extracted (AVE), Composite Reliability (CR), dan Cronbach Alpha (CA) Factor

\begin{tabular}{|c|c|c|c|c|}
\hline Question Item & FL & $\mathrm{CR}$ & $\mathrm{CA}$ & AVE \\
\hline $\begin{array}{l}\text { Destination } \\
\text { Image (CD) }\end{array}$ & & & & \\
\hline $\begin{array}{l}\text { (X1.1) Umbul } \\
\text { Ponggok is } \\
\text { comfortable } \\
\text { place }\end{array}$ & 0.611 & \multirow{5}{*}{0.797} & \multirow{5}{*}{0.659} & \multirow{5}{*}{0.498} \\
\hline $\begin{array}{l}\text { (X1.2) the } \\
\text { price is } \\
\text { affordable }\end{array}$ & 0.653 & & & \\
\hline $\begin{array}{l}\text { (X1.3) I visit } \\
\text { Umbul }\end{array}$ & & & & \\
\hline $\begin{array}{l}\text { Ponggok to } \\
\text { have } \\
\text { snorkeling like } \\
\text { I experience in } \\
\text { beach }\end{array}$ & 0.758 & & & \\
\hline $\begin{array}{l}\text { (X1.4) Umbul } \\
\text { Ponngok has } \\
\text { various kind of } \\
\text { fishes as } \\
\text { snorkeling } \\
\text { object }\end{array}$ & 0.785 & & & \\
\hline \multicolumn{2}{|c|}{ Service Quality (KP) } & \multirow{5}{*}{0.755} & & \\
\hline $\begin{array}{l}\text { (X2.1) No need } \\
\text { to queue while } \\
\text { ticketing }\end{array}$ & 0.715 & & \multirow{4}{*}{0.569} & \multirow{4}{*}{0.445} \\
\hline $\begin{array}{l}\text { (X2.2) } \\
\text { Tourists feel } \\
\text { comfortable } \\
\text { on service and } \\
\text { facility } \\
\text { provided by } \\
\text { owner }\end{array}$ & 0.439 & & & \\
\hline $\begin{array}{l}\text { X2.3) The } \\
\text { guards is } \\
\text { friendly to } \\
\text { help }\end{array}$ & 0.687 & & & \\
\hline $\begin{array}{l}\text { (X2.4) All } \\
\text { important } \\
\text { utilities are } \\
\text { provided }\end{array}$ & 0.777 & & & \\
\hline $\begin{array}{l}\text { Perceived } \\
\text { Value (PV) }\end{array}$ & & & & \\
\hline $\begin{array}{l}\text { (Y.1) I feel } \\
\text { comfortable in } \\
\text { Umbul } \\
\text { Ponggok }\end{array}$ & 0.781 & 0.746 & 0.489 & 0.497 \\
\hline
\end{tabular}

Table 2, cont.

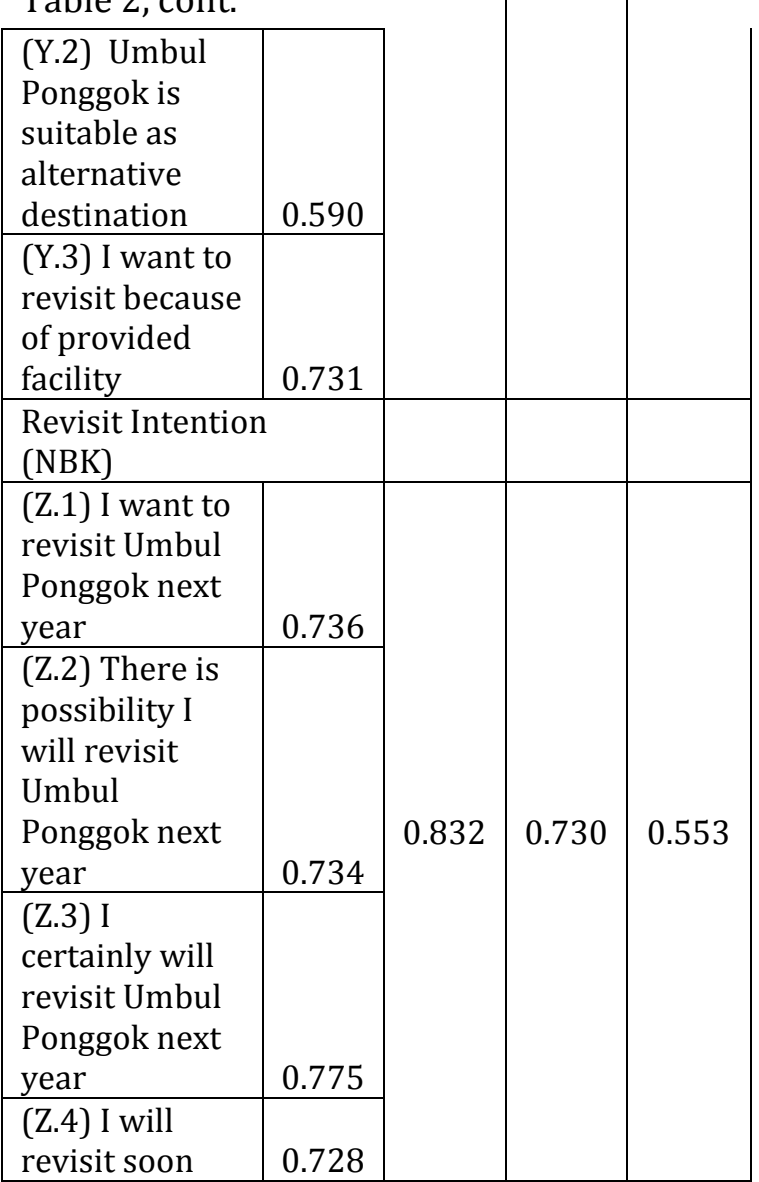

From table 2 loading value for X1.1 from DI latent variable is 0.611 , loading value for X1.2 from DI latent variable is 0.653 and so on. An indicator will be eliminated if the value is lower than 0.4 . Based on the table above, it appears that the entire value of the loading indicator from each latent variable is more than 0.4 . So that, testing phase has completed. In addition, all the indicators have low loading cross value to other latent variables that indicate good discriminant validity (Ringle n.d. 2014).

\section{RESULT}

\section{Validity and Reliability}

To test discriminant validity, suggested AVE value is above 0.5. Based on Table 2, the lowest AVE value in DI, SR, and PV variable is lower than 0.5. Because AVE value approaches 0.5 it is considered to remain included (Ringlen.d. 
2014). Reliability evaluation assessed by Cronbach alpha (CA) and composite reliability (CR). Suggested CA value is above 0.6 while the limit of CR value is above 0.7. Table 2 shows that the lowest CA value from PV latent variable is 0.489 . CR value, which is above 0.7 , requires limit of $C R$ value.

\section{Inner Model Evaluation (Structural Model)}

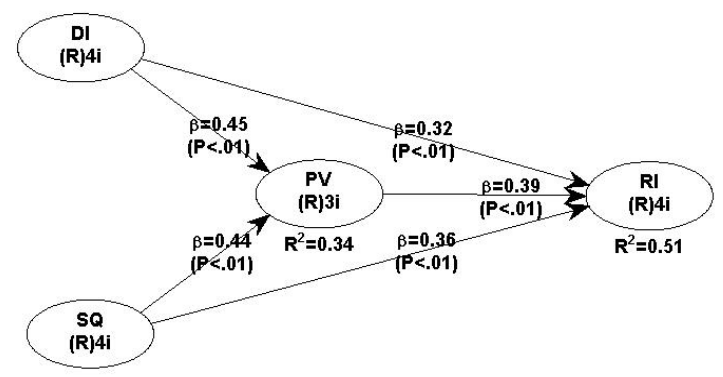

Figure 2. Result of structural equation model (SEM)

Tabel.3. Research Model Estimation (N: 183)

\begin{tabular}{|c|c|c|c|c|}
\hline $\begin{array}{c}\text { Laten } \\
\text { Variables }\end{array}$ & $\begin{array}{l}\text { Direct } \\
\text { Affect }\end{array}$ & Path & \multicolumn{2}{|c|}{ P values } \\
\hline \multicolumn{2}{|c|}{$\begin{array}{l}\text { Destination image } \rightarrow \\
\text { Perceived Value (X1) }\end{array}$} & 0.45 & \multicolumn{2}{|c|}{$<0,001$} \\
\hline \multicolumn{2}{|c|}{$\begin{array}{l}\text { Destination image } \rightarrow \\
\text { Revisit Intention }(\mathrm{X} 2)\end{array}$} & 0.32 & \multicolumn{2}{|c|}{$<0,001$} \\
\hline \multicolumn{2}{|c|}{$\begin{array}{l}\text { Service Quality } \rightarrow \\
\text { Perceived Value (X4) }\end{array}$} & 0.44 & \multicolumn{2}{|c|}{$<0,001$} \\
\hline \multicolumn{2}{|c|}{$\begin{array}{l}\text { Service Quality } \rightarrow \text { Revisit } \\
\text { Intention X5) }\end{array}$} & 0.36 & \multicolumn{2}{|c|}{$<0,001$} \\
\hline \multicolumn{2}{|c|}{$\begin{array}{l}\text { Perceived Value } \rightarrow \\
\text { Revisit Intention (X7) }\end{array}$} & 0.39 & \multicolumn{2}{|c|}{$<0,001$} \\
\hline \multicolumn{2}{|c|}{ Indirect Affect } & \multicolumn{3}{|c|}{$P$ values } \\
\hline \multicolumn{2}{|c|}{$\begin{array}{l}\text { Destination image } \rightarrow \\
\text { Perceived Value } \rightarrow \\
\text { Revisit Intention (X3) }\end{array}$} & \multicolumn{3}{|c|}{$<0,001$} \\
\hline \multicolumn{2}{|c|}{$\begin{array}{l}\text { Service Quality } \rightarrow \\
\text { Perceived Value } \rightarrow \\
\text { Revisit Intention (X6) }\end{array}$} & \multicolumn{3}{|c|}{$<0,001$} \\
\hline \multirow{2}{*}{\multicolumn{2}{|c|}{ Goodness of Fit }} & APC & $2 S$ & AVIF \\
\hline & & 0.374 & 47 & 0.990 \\
\hline
\end{tabular}

\section{a. Testing of Direct Impact (Direct Effect)}

Test was conducted in figure2, the results support hypothesizes which is influence of destination image and quality service toward revisit intention through perceived value. Thus, hypothesis $\mathrm{H} 1, \mathrm{H} 2, \mathrm{H} 4, \mathrm{H} 5, \mathrm{H} 7$ are positively and significantly answered. Value of P-values between destination image and perceived value $<0.001$, which is smaller by 0.05 from significance level. This means that the destination image significantly affects perceived value. Then, the path of coefficient value of the destination image toward perceived value is 0,45 . The positive coefficient value means the destination image positively affects perceived value which means the hypothesis $\mathrm{H} 1$ is accepted. Value of P-values between destination image and revisit intention $<0.001$, which is smaller 0.05 than significance level. This means that significantly influences the destination image of revisit intention. Then, the path coefficient value of the destination image toward revisit intention is 0,32 . The coefficient of the positive value means the destination image positively influences revisit intention which means hypothesis $\mathrm{H} 2$ is accepted. Value of P-values between service quality and perceived value $<0.001$, which is smaller 0.05 than significance level. This means service quality significantly influences the perceived value. Then, the path of coefficient value of service quality to perceived value is 0,44 . Coefficient values are positive means service quality positively influences perceived value which means the $\mathrm{H} 4$ hypothesis is accepted. Value of P-values between service quality and revisit intention $<0.001$, which is smaller 0.05 than significance level. This means service quality significantly influences revisit intention. Then, the path of coefficient value of service quality to revisit intention is 0,36. Coefficient values are positive means service quality positively influences revisit intention which means H5 hypothesis is accepted. Value of P-values between perceived value and revisit intention $<0.001$, which is smaller 0.05 than significance level. This means that perceived value significantly influences the repurchase intention. Then, the path of coefficient value of perceived value to repurchase intention is 0,39 . Coefficient values are positive means perceived value positively affects revisit intention which means $\mathrm{H} 7$ hypothesis is accepted.

\section{b. Testing of Indirect Influence (Indirect Effect)}

Based on figure 2, the value of P-values between destination image and revisit intention is $<0.001$, which is smaller 0.05 than significance 
level. This means that the indirect influence of destination image to revisit intention through perceived value significantly shows that the H3 hypothesis is accepted. Furthermore, value of Pvalues between service quality and revisit intention is $<0.001$, which is smaller 0.05 than significance level. This means that the indirect influence of service quality to revisit intention, through perceived value significantly shows that the hypothesis $\mathrm{H} 6$ is accepted. Goodness of fit based on Table 2, APC value is 0.374 , ARS is 0.447 , and AVIF is 0.990, which lesser than 5 . This means that the proposed model has been fit (Ringle n.d.2014).

\section{CONCLUSION}

This study found that the structural relationship between all variables in this study using a data tested in Umbul ponggok. In addition, the roe of perceived value mediating between destination image and service quality toward revisit intention. The result shows that revisit intention can occur because satisfying service quality. Then, revisit intention occurs because tourists consciously aware of the destination image of planned spot. By destination image the tourists feel comfortable and happy to visit place which has a good image. Perceived value received from the destination image and service quality possibly make tourists want to revisit Umbul ponggok as the results of this study states that all hypothesis is support.

\section{MANAGERIAL IMPLICATION}

The development of tourism will continue progressing and rapidly developed so that the government has important role in maintaining, preserving, and building an attractive worldwide tourism that can compete with other tourism. By creating a destination image and service quality in particular place will help the government improving revisit intention of tourists and form a perceived value that is useful to affect revisit intention of tourists.

\section{ACKNOWLEDGMENT}

The authors would like to thank Ms. Dr. Naili Farida, M.Si for the direction and advises to complete this research.

\section{REFERENCES}

Ã, C. C., \& Tsai, D. (2007). How destination image and evaluative factors affect behavioral intentions?, 28, 1115-1122. http://doi.org/10.1016/j.tourman.2006.07.0 07

Abubakar, A. M., \& Ilkan, M. (2016). Impact of online WOM on destination trust and intention to travel: A medical tourism perspective. Journal of Destination Marketing \& Management, 1-10. http://doi.org/10.1016/j.jdmm.2015.12.005

Authors, F. (2011). Role of switching costs in the service quality, perceived value, customer satisfaction and. http://doi.org/10.1108/135558511111432 40

Chen, Y. C., Shang, R. A., \& Li, M. J. (2014). The effects of perceived relevance of travel blogs' content on the behavioral intention to visit a tourist destination. Computers in Human Behavior, 30, 787-799. http://doi.org/10.1016/j.chb.2013.05.019

Croes, R. R. (2006). A paradigm shift to a new strategy for small island economies: Embracing demand side economics for value enhancement and long term economic stability. Tourism Management, 27(3), 453465.

http://doi.org/10.1016/j.tourman.2004.12.0 03

Dye, J. C. G. T., Groth, J. C., \& Dye, R. T. (2007). Research and concepts Service quality: perceived value, expectations, shortfalls, and bonuses.

Ferns, B. H., \& Walls, A. (2012). Enduring travel involvement, destination brand equity, and travelers' visit intentions: A structural model analysis. Journal of Destination Marketing and Management, 1(1-2), 27-35. http://doi.org/10.1016/j.jdmm.2012.07.002

Gurtner, Y. (2016). Journal of Hospitality and 
Tourism Management Returning to paradise: Investigating issues of tourism crisis and disaster recovery on the island of Bali. Journal of Hospitality and Tourism Management, 28, 11-19. http://doi.org/10.1016/j.jhtm.2016.04.007

Hapsari, R., Clemes, M., \& Dean, D. (2016). The Mediating Role of Perceived Value on the Relationship between Service Quality and Customer Satisfaction: Evidence from Indonesian Airline Passengers. Procedia Economics and Finance, 35(October 2015), 388-395. http://doi.org/10.1016/S22125671(16)00048-4

Henderson, J. C. (2016). Halal food, certi fi cation and halal tourism: Insights from Malaysia and Singapore. TMP, 19, 160-164. http://doi.org/10.1016/j.tmp.2015.12.006

Horng, J. S., Liu, C. H., Chou, H. Y., \& Tsai, C. Y. (2012). Understanding the impact of culinary brand equity and destination familiarity on travel intentions. Tourism Management, 33(4), 815-824. http://doi.org/10.1016/j.tourman.2011.09.0 04

Kim, S., \& Jun, J. (2016). The impact of event advertising on attitudes and visit intentions. Journal of Hospitality and Tourism Management, 29, 1-8. http://doi.org/10.1016/j.jhtm.2016.04.002

Konecnik, M., \& Gartner, W. C. (2007). Customerbased brand equity for a destination. Annals of Tourism Research, 34(2), 400-421. http://doi.org/10.1016/j.annals.2006.10.00 5

Kuo, Y. F., Wu, C. M., \& Deng, W. J. (2009). The relationships among service quality, perceived value, customer satisfaction, and post-purchase intention in mobile valueadded services. Computers in Human Behavior, 25(4), 887-896. http://doi.org/10.1016/j.chb.2009.03.003

Lai, I. K. W., \& Hitchcock, M. (2016). A comparison of service quality attributes for stand-alone and resort-based luxury hotels in Macau: 3Dimensional importance-performance analysis. Tourism Management, 55, 139-159. http://doi.org/10.1016/j.tourman.2016.01.0 07

Lai, W., \& Chen, C. (2011). Behavioral intentions of public transit passengers - The roles of service quality, perceived value, satisfaction and involvement. Transport Policy, 18(2), 318-325.

http://doi.org/10.1016/j.tranpol.2010.09.00 3

Law, A., Lacy, T. De, Lipman, G., \& Jiang, M. (2016). Transitioning to a green economy: the case of tourism in Bali, Indonesia. Journal of Cleaner Production, 111, 295-305. http://doi.org/10.1016/j.jclepro.2014.12.07 0

Liu, C.-H. S., \& Lee, T. (2016). Service quality and price perception of service: Influence on word-of-mouth and revisit intention. Journal of Air Transport Management, 52, 42-54. http://doi.org/10.1016/j.jairtraman.2015.12 .007

Ramseook-Munhurrun, P., Seebaluck, V. N., \& Naidoo, P. (2015). Examining the Structural Relationships of Destination Image, Perceived Value, Tourist Satisfaction and Loyalty: Case of Mauritius. Procedia - Social and Behavioral Sciences, 175(230), 252-259. http://doi.org/10.1016/j.sbspro.2015.01.11 98

Rasoolimanesh, S. M., Dahalan, N., \& Jaafar, M. (2016). Journal of Hospitality and Tourism Management Tourists $\hat{a}^{\mathrm{TM}}$ perceived value and satisfaction in a community-based homestay in the Lenggong Valley World Heritage Site. Journal of Hospitality and Tourism Management, 26, 72-81. http://doi.org/10.1016/j.jhtm.2016.01.005

Ringle, C. M. (n.d.). PARTIAL LEAST SQUARES STRUCTURAL EQUATION MODELING ( PLSSEM).

Sen, S., \& Lerman, D. (2007). Why are you telling me this? An examination into negative consumer reviews on the web. Journal of Interactive Marketing, 21(4), 76-94. http://doi.org/10.1002/dir.20090

Stylos, N., Vassiliadis, C. A., Bellou, V., \& Andronikidis, A. (2016). Destination images, holistic images and personal normative beliefs: Predictors of intention to revisit a destination. Tourism Management, 53, 40-60. http://doi.org/10.1016/j.tourman.2015.09.0 06

Sultan, M. A. (2012). PROSES PEMBENTUKAN 
PERILAKU, 16(1), 107-118.

Tan, W. (2016). Journal of Destination Marketing \& Management Repeat visitation : A study from the perspective of leisure constraint, tourist experience, destination images, and experiential familiarity. Journal of Destination Marketing \& Management, (2013), 1-10. http://doi.org/10.1016/j.jdmm.2016.04.003

Tosun, C., Dedeo??lu, B. B., \& Fyall, A. (2015). Destination service quality, affective image and revisit intention: The moderating role of past experience. Journal of Destination Marketing and Management, 4, 222-234. http://doi.org/10.1016/j.jdmm.2015.08.002

Vitouladiti, 0. (2014). Content Analysis as a Research Tool for Marketing, Management and Development Strategies in Tourism. Procedia Economics and Finance, 9(Ebeec 2013), 278-287. http://doi.org/10.1016/S22125671(14)00029-X

Whang, H., Yong, S., \& Ko, E. (2016). Pop culture, destination images, and visit intentions: Theory and research on travel motivations of Chinese and Russian tourists. Journal of Business Research, 69(2), 631-641. http://doi.org/10.1016/j.jbusres.2015.06.02 0

Zhang, J., Wang, J., Min, S. D., Chen, K. K., \& Huang, H. (2016). Influence of curriculum quality and educational service quality on student experiences: A case study in sport management programs. Journal of Hospitality, Leisure, Sport \& Tourism Education, 18, 81-91. http://doi.org/10.1016/j.jhlste.2016.04.001 